\title{
Exploration of silicon functions to integrate with biotic stress tolerance and crop improvement
}

\author{
Xiu-Peng Song ${ }^{1}$, Krishan K. Verma' , Dan-Dan Tian², Xiao-Qiu Zhang ${ }^{1}$, Yong-Jian Liang ${ }^{3}$, Xing Huang ${ }^{1}$, \\ Chang-Ning $\mathrm{Li}^{1}$ and Yang-Rui Li ${ }^{{ }^{*}}$
}

\begin{abstract}
In the era of climate change, due to increased incidences of a wide range of various environmental stresses, especially biotic and abiotic stresses around the globe, the performance of plants can be affected by these stresses. After oxygen, silicon (Si) is the second most abundant element in the earth's crust. It is not considered as an important element, but can be thought of as a multi-beneficial quasi-essential element for plants. This review on silicon presents an overview of the versatile role of this element in a variety of plants. Plants absorb silicon through roots from the rhizospheric soil in the form of silicic or monosilicic acid. Silicon plays a key metabolic function in living organisms due to its relative abundance in the atmosphere. Plants with higher content of silicon in shoot or root are very few prone to attack by pests, and exhibit increased stress resistance. However, the more remarkable impact of silicon is the decrease in the number of seed intensities/soil-borne and foliar diseases of major plant varieties that are infected by biotrophic, hemi-biotrophic and necrotrophic pathogens. The amelioration in disease symptoms are due to the effect of silicon on a some factors involved in providing host resistance namely, duration of incubation, size, shape and number of lesions. The formation of a mechanical barrier beneath the cuticle and in the cell walls by the polymerization of silicon was first proposed as to how this element decreases plant disease severity. The current understanding of how this element enhances resistance in plants subjected to biotic stress, the exact functions and mechanisms by which it modulates plant biology by potentiating the host defence mechanism needs to be studied using genomics, metabolomics and proteomics. The role of silicon in helping the plants in adaption to biotic stress has been discussed which will help to plan in a systematic way the development of more sustainable agriculture for food security and safety in the future.
\end{abstract}

Keywords: Antioxidants, Biotic stress, Crop improvement, Physiology, Sustainable agriculture, Silicon

\footnotetext{
*Correspondence: liyr@gxaas.net Guangxi, China

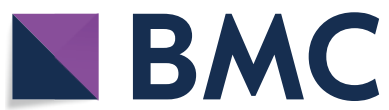

${ }^{1}$ Sugarcane Research Institute, Guangxi Academy of Agricultural

Sciences/Key Laboratory of Sugarcane Biotechnology and Genetic Improvement (Guangxi), Ministry of Agriculture and Rural Affairs/Guangxi

Key Laboratory of Sugarcane Genetic Improvement, Nanning 530007,

Full list of author information is available at the end of the article

\begin{abstract}
Background
The earth's surface is covered with $28.8 \%$ (dry wt. basis) of silicon $(\mathrm{Si})$ after oxygen, but the existence of $\mathrm{Si}$ in its pure form is extremely rare [1-3]. Silicon is found as quartz, feldspar, mica and clay minerals in the earth's crust [2, $4,5]$. In biological systems, $\mathrm{Si}$ occurs in various forms of amorphous silica $\left(\mathrm{SiO}_{2} \mathrm{nH}_{2} \mathrm{O}\right)$ namely, as phytoliths and in silica rich plants $[6,7]$. The biogenic share of silicon is about $1-3 \%$ of the total Si pool in the soil [8].
\end{abstract}

(c) The Author(s) 2021. This article is licensed under a Creative Commons Attribution 4.0 International License, which permits use, sharing, adaptation, distribution and reproduction in any medium or format, as long as you give appropriate credit to the original author(s) and the source, provide a link to the Creative Commons licence, and indicate if changes were made. The images or other third party material in this article are included in the article's Creative Commons licence, unless indicated otherwise in a credit line to the material. If material is not included in the article's Creative Commons licence and your intended use is not permitted by statutory regulation or exceeds the permitted use, you will need to obtain permission directly from the copyright holder. To view a copy of this licence, visit http://creativeco mmons.org/licenses/by/4.0/. The Creative Commons Public Domain Dedication waiver (http://creativecommons.org/publicdomain/ zero/1.0/) applies to the data made available in this article, unless otherwise stated in a credit line to the data. 
The numerous advantages of Si to crops are now widely acknowledged [3,9-12]. The plant-available forms of Si may be limited $[1,13]$. The plant biologists/physiologists recognized the significance of $\mathrm{Si}$ as early as the nineteenth century [14-16]. Silicon is now widely considered as a beneficial element $[2,17]$, but it is still considered non-essential for plant growth and development [18]. Lewin and Reimann [19] demonstrated that the Si played a major metabolic role in living organisms due to its relatively abundance in nature. According to Epstein [20], silicon is essential for plant growth, acts as a mechanical barrier and provides resistance against plant pathogens and herbivores, and as such drawn the more attention of its role in plant biology. Furthermore, [9] found that the majority of crops contain significant quantity of $\mathrm{Si}$, implying that this is unlikely to be a result of stochastic element absorption, similar to how evolutionary mechanisms have evolved for uptake and accumulation of other nutritional elements.

Furthermore, Si uptake by plant roots can be adaptive in response to changing atmospheric variables namely, stress, whether abiotic or biotic [2, 3, 21, 22], and thus is not always necessary, but arguably important. While the importance of this feature to plants is still argued, considerable progress has been made in our understanding of $\mathrm{Si}$ uptake and accumulation in plants. Plants can be classified as hyper-accumulators, accumulators, passive accumulators and non-accumulating varieties. Furthermore, the benefits of application of liquid forms of Si have been demonstrated, especially during plant stress tolerance. Limited studies have been carried out whether Si plays a significant role in plant metabolic activities [2, 10, 22, 23].

The experiments showing the impact of $\mathrm{Si}$ on plant tolerance to environmental stresses [3, 24-28] have been carried out at physiological, molecular and ecological levels [12, 29-31]. The current research articles published on the mitigation of plant stress by $\mathrm{Si}$ demonstrates the interest in this area $[3,11,22,32,33]$. However, none of the researchers took into account the possibility of $\mathrm{Si}$ interacting with fundamental plant omics. Indeed, most studies have concentrated on species-specific and narrow aspects of $\mathrm{Si}$-plant stress interactions. Some studies have contributed to our understanding of the larger effects of $\mathrm{Si}$ on plant growth and defence, including interactions with plant diseases, but the mechanisms underlying these effects are still unknown. The present review, briefly discusses the physiological and molecular basis of amelioration of biotic stress conditions in plants by silicon and the mechanisms involved.

\section{Biotic stress}

In natural conditions, plants suffer from various types of stresses caused by living organisms like bacteria, viruses, fungi, parasites, significant and non-significant insects. Like livestock, plants also have a defence system, which provides tolerance against environmental stresses. On invasion by pathogens and herbivorous pests, plants make use of pre-existing physical, chemical and mechanical barriers to protect themselves. The plant defence functions are also activated upon attack by pest; plant protection functions as a unit to decrease negative responses of biotic stress (Table 1). The stress induced defence system is associated with complex interconnected pathways of signal transduction in which phytohormones namely, abscisic acid (ABA), ethylene (ETH), jasmonic acid (JA) and salicylic acid (SA) plays an important role $[2,13,34-36]$. The biotic stress may enhance in the coming years because of climate change. The costs linked with stress are potentially enormous, and the effects of the stress may have a great impact on sustainable agriculture and environmental systems [3].

\section{Silicon mitigates biotic stress in plants: physical and mechanical barriers}

Plants grown under normal conditions are exposed to environmental stresses such as biotic (caused by viral and bacterial pathogens or fungi and herbivores) and abiotic stresses (saline, high and low temperature, flooding, UV, wind, drought, metal toxicity, light and mineral deficiency or excess). Supplementing plants with Si have been shown to enhance plant tolerance to mammalian, arthropod, and molluscan herbivores, fungal and bacterial pathogens, viruses and nematodes $[2,21,22,26,37$, 38]. The physical defence induced by Si deposition in plant parts in the form of phytoliths (largely composed of $\mathrm{SiO}_{2}$ ) was one of the first theories proposed for studying stress tolerance to pests $[39,40]$. Silicon translocated from the soil solution as monosilicic acid into plants. Monosilicic acid polymerizes to form phytoliths, which are accumulated within the plant in an irreversible manner [20, 29]. Deposition of phytoliths enhances plant immunity and physical resilience, and serves as a physical barrier to fungal penetration [41, 42]. Silicon deposition may also wear away the feeding mouthparts, or mandibles of insects [43], decrease plant digestibility for both insect and mammalian herbivores [21, 44, 45], and have an adverse effect on herbivores [46]. Importantly, plant tissue silicification may be induced more in those plants which are highly attacked by various organisms [42, 47]. Silicon also affects the plant metabolites associated with plant defence $[10,48,49]$, such as chitinase (CHT), $\beta-1,3$ glucanase, phenylalanine ammonia-lyase (PAL), polyphenol oxidase (PPO), in a number of plant-pathogens such as necrotrophic, biotrophic and hemibiotrophic pathogens [37, 50, 51]. Silicon-induced increased production of flavonoids, peroxidases (PODs) and chitinase (CHT) 
Table 1 The adaptive mechanisms of silicon in crop plants against biotic stress

\begin{tabular}{|c|c|c|c|}
\hline Stress/disease & Plant & Action & Source \\
\hline Anthracnose & Tomato (Solanum lycopersicum) & $\begin{array}{l}\text { Cuticle thickness and fruit firmness } \\
\text { enhanced }\end{array}$ & [107] \\
\hline $\begin{array}{l}\text { Bacterial speck, Bacterial wilt, Fusarium } \\
\text { crown and root rot }\end{array}$ & $"$ & $\begin{array}{l}\text { Upgraded physiological, biochemical and } \\
\text { molecular traits }\end{array}$ & {$[98,106,108,109]$} \\
\hline Early blight & $"$ & $\begin{array}{l}\text { Improve biochemical and molecular } \\
\text { aspects }\end{array}$ & [72] \\
\hline Rice leaf folder & Rice (Oryza sativa) & $\begin{array}{l}\text { Food/grain quality and conversion efficien- } \\
\text { cies decreased }\end{array}$ & [110] \\
\hline Brown plant hopper & $"$ & Extraction of honeydew reduced & [111] \\
\hline Fall armyworm & $"$ & $\begin{array}{l}\text { Damage feeding preference as well as } S \text {. } \\
\text { frugiperda larval survival }\end{array}$ & [112] \\
\hline Sugarcane borer & $"$ & $\begin{array}{l}\text { Feeding injury decreased and upregulated } \\
\text { exposure to unfavorable climatic vari- } \\
\text { ables and natural enemies arising from } \\
\text { decreased boring success }\end{array}$ & [113] \\
\hline $\begin{array}{l}\text { Blast, Brown spot, Grain discoloration, Leaf } \\
\text { scald and Sheath blight }\end{array}$ & $"$ & $\begin{array}{l}\text { Enhanced physical, biochemical and } \\
\text { molecular activities }\end{array}$ & {$[41,51,67,83,114-120]$} \\
\hline Diatraeasaccharalis & Sugarcane (Saccharum spp.) & $\begin{array}{l}\text { Upgrade/maintain leaf cuticle thickening } \\
\text { and leaf stomata crystals }\end{array}$ & {$[121]$} \\
\hline Stalk borer & $"$ & Decreased \% stalks and length bored & [122] \\
\hline Brown rust & $"$ & Physical and biochemical & [123] \\
\hline Euschistusheros & Soybean (Glycine max) & $\begin{array}{l}\text { Upregulated non-preference and antibiosis } \\
\text { resistances }\end{array}$ & [124] \\
\hline Powdery mildew & Arabidopsis (Arabidopsis thaliana) & $\begin{array}{l}\text { Physio-biochemical activities increased } \\
\text { and/or balanced }\end{array}$ & {$[58,75,125]$} \\
\hline $\begin{array}{l}\text { Black sigatoka } \\
\text { Fusarium wilt } \\
\text { Root rot } \\
\text { Xanthomonas wilt }\end{array}$ & Banana (Musa spp.) & " & [126-129] \\
\hline Powdery mildew & Barley (Hordeum vulgare) & Improve physiological performance & [130] \\
\hline Angular leaf spot & Bean (Phaseolus vulgaris) & $"$ & [131] \\
\hline Powdery mildew & Black gram (Vigna mungo) & Enhanced expression of genes & [132] \\
\hline Dollar spot & Bentgrass (Agrostis stolonifera) & $\begin{array}{l}\text { Improve physiological and biochemical } \\
\text { characteristics }\end{array}$ & {$[90,133]$} \\
\hline Powdery mildew & Bitter gourd (Momordica charantia) & Enhanced biochemical activities & [134] \\
\hline Anthracnose & Capsicum (Capsicum annuum) & $\begin{array}{l}\text { Improve physiological and biochemical } \\
\text { characteristics }\end{array}$ & [135] \\
\hline Fruit decay & Cherry (Prunus avium) & Improve biochemical parameters & [136] \\
\hline Fusarium root rot and Postharvest pink rot & Chinese cantaloupe & $\begin{array}{l}\text { Improve physiological and biochemical } \\
\text { characteristics }\end{array}$ & {$[137,138]$} \\
\hline Leaf rust and Root-knot Nematode & Coffee (Coffea arabica) & $"$ & {$[139,140]$} \\
\hline Anthracnose & Common bean (Phaseolus vulgaris) & Improve biochemical traits & {$[141,142]$} \\
\hline Fusarium wilt & Cotton (Gossypium spp.) & $\begin{array}{l}\text { Improve physiological and biochemical } \\
\text { characteristics }\end{array}$ & [143] \\
\hline $\begin{array}{l}\text { Crown and root rot, Fusarium wilt and } \\
\text { Powdery mildew }\end{array}$ & Cucumber (Cucumis sativus) & $"$ & {$[37,144-148]$} \\
\hline Decay & Hami melons (Cucumis melo) & Improve biochemical activities & [149] \\
\hline Downy mildew & Lettuce (Lactuca sativa) & $\begin{array}{l}\text { Enhance physiological and biochemical } \\
\text { activities }\end{array}$ & [150] \\
\hline Bacterial fruit blotch and Powdery mildew & Melon (Cucumis melo) & Improve biochemical capacity & {$[151,152]$} \\
\hline Pink rot disease and Powdery mildew & Muskmelon (Cucumis melo) & $\begin{array}{l}\text { Enhance physiological and biochemical } \\
\text { activities }\end{array}$ & {$[146,153]$} \\
\hline Basal stem rot & Oil palm (Elaeis guineensis) & Balance physical characteristics & [154] \\
\hline Brown spot & Pea (Pisum sativum) & Balance biochemical activities & {$[155]$} \\
\hline
\end{tabular}


Table 1 (continued)

\begin{tabular}{llll}
\hline Stress/disease & Plant & Action & Source \\
\hline Downy mildew & Pearl millet (Pennisetum glaucum) & $\begin{array}{c}\text { Enhance physiological and biochemical } \\
\text { activities }\end{array}$ & {$[156]$} \\
Fusarium patch and Gray leaf spot & Perennial ryegrass (Lolium perenne) & $"$ & {$[49,157]$} \\
$\begin{array}{l}\text { Dry rot } \\
\text { Powdery mildew }\end{array}$ & Potato (Solanum tuberosum) & $"$ & {$[137]$} \\
$\begin{array}{l}\text { Blast, leaf blast, leaf streak, powdery mildew } \\
\text { and spot blotch }\end{array}$ & Pumpkin (Cucurbita spp.) & $"$ & {$[158]$} \\
\hline
\end{tabular}

in some necrotrophic pathogens have been reported [37, 52].

Current research has looked into the interactions between $\mathrm{Si}$ and plant defence signaling transduction pathways, specifically the main plant hormone signaling pathways. Plants develop a complex and unique blend of SA (generally linked with pathogens of (hemi)biotrophic), JA (generally linked with pathogens of necrotrophic and insect herbivores), and ETH (which is usually regarded as 'fine-tuning' the JA defence action) in response to attack or infection [53, 54]. Plant hormone signaling has been shown to be important for Si-mediated plant tolerance to disease stress [50]. Ye et al. [55] demonstrated that the JA pathway needed for $\mathrm{Si}$ - induced insect herbivore tolerance uses JA-deficient rice mutants. Several other researchers demonstrated that the capacity of Si to induce JA-dependent defence functions, such as indirect insect herbivore attraction by changing the composition of herbivore-induced plant volatiles (HIPVs) generated during herbivore attack [56, 57]. Silicon increased SAdependent defence genes in response to infection from biotrophic fungal pathogen, but induction of the SA pathway was not needed by $\mathrm{Si}$ to increase stress tolerance [58]. Van Bockhaven et al. [59] noted that the role of $\mathrm{Si}$ in increasing tolerance against necrotrophic fungal pathogen (Cochliobolus miyabeanus) was not dependent on the JA and SA pathways. Rather, they proposed that Si deactivated pathogen ethylene production by preventing the pathogen from hijacking the plant's ETH mechanism. These findings indicated that the Si plays a significant role in multiple phytohormone signaling pathways to mitigate plant biotic stress $[21,28,60]$.

Silicon can also help to overcome certain (hemi)biotrophic pathogens and the ability of some insects to suppress plant-induced defenses. When a plant detects a biotic threat, it triggers the defence phytohormone signaling pathway. Pathogen-associated (PAMPs), damageassociated (DAMPs) and herbivore-associated molecular patterns (HAMPs) are examples of conserved molecular patterns that differ depending on the plant disease $[61,62]$. The identification of these molecules by pattern recognition receptors (PRRs), often in conjunction with identification of other pathogens/insects effector proteins, may activate a plant defense response (known as PAMP-triggered immunity [PTI] or effector-triggered immunity [ETI]) that is sufficient to induce plant stress $[62,63]$. Though necrotrophic pathogens do not develop effector proteins [53], (hemi)biotrophic pathogens and herbivores do, effectively suppressing the plant immune response by suppressing PTI and ETI [64, 65]. Silicon accumulation in the plant apoplast is likely to prevent pathogen effectors from reaching their target sites, preventing the pathogen from inhibiting the plant defence response [58]. Silicon may be able to help in overcoming plant defence suppression, by enabling a complete defence response to be initiated when a biotic threat is present. One of the first cellular responses following identification of PAMPs or HAMPs is formation of reactive oxygen species (ROS), which helps in assessing biotic stress.

A common mechanism by which $\mathrm{Si}$ is proposed to function and mitigate biotic stress is ROS and enhanced antioxidant metabolism (a similar mechanism is involved in abiotic stress) [66]. Generation of ROS and increasing oxidative metabolism help to reduce oxidative damage to the plants $[67,68]$. ROS generation and increased antioxidant metabolism have been linked to stress due to pathogen (bacterial and fungal) infection, as well as damage to the plant from chewing and sucking insects [67-69]. ROS may have a negative and direct effect on biotic stress [70]. However, ROS play a number of signaling actions in different defence signaling pathways with plant hormones, such as JA and SA [53, 70-72]. Additionally, ROS may stimulate plant defence genes, resulting in the accumulation of defence metabolic compounds such as phytoalexins and allelochemicals in the plants [73]. Van Bockhaven et al. [59] demonstrated that the primary plant metabolism, i.e. photorespiration and the development of ROS, play a significant role in the broad-spectrum impact of $\mathrm{Si}$ on disease mitigation. Silicon is needed for sustenance of life processes in diatoms (algal phytoplankton), including replication of DNA [74], and evaluating how $\mathrm{Si}$ affects the cellular metabolism in algae and other primitive plants could provide valuable insights into how $\mathrm{Si}$ functions and 
its mechanisms of action in angiosperms. The production of ROS as a by-product of fundamental life processes, as well as the implications of an association of Si with oxidation/antioxidant metabolism in numerous plant stress studies, indicate that this is a promising research avenue for determining fundamental role of $\mathrm{Si}$ in lower and higher plants.

In order to better understand how $\mathrm{Si}$ affects plant gene expression, researchers must combine transcriptomic approaches, i.e. microarrays with more focused assays, like real-time quantitative PCR (qRT-PCR). Fauteux et al. [75] observed that the defence genes of infected plants are upregulated and primary metabolism genes are downregulated. After the application of $\mathrm{Si}$, the defence genes were less affected, and that there was no evidence to indicate that $\mathrm{Si}$ had an effect without pathogenic stress condition. Similarly, Chain et al. [76] and Van Bockhaven et al. [59] noticed that applying Si to plants almost completely eliminated the pathogen stress effects at the transcriptomics level (Tables 2, 3). In numerous studies, a higher Si content in the rhizospheric soil and growth medium has been shown to improve crop resistance to pest infection. With Si supplementation, white backed plant hoppers (Sogatella frucifera) have shown decreased feeding, decreased growth durability, decreased fecundity, and reduced population growth [77]. Furthermore, the foliar application of $\mathrm{Si}$ as calcium silicate $\left(\mathrm{Ca}_{2} \mathrm{SiO}_{4}\right)$ to wheat (Triticum spp.), cotton (Gossypium spp.), sugarcane (Saccharum spp.), and cucumber (Cucumis spp.) enhanced white fly nymph mortality, resulting in substantial loss of crop production against normal plants [78]. The Oryza sativa plant roots with high Si content are resistant to rootknot nematode infection [79]. Silicon supplementation can also help rice plants resist attacks from green leaf hoppers, plant hoppers, and stem maggots [80]. Furthermore, leaf-eating caterpillars have been found to have a low preference for silicified plant parts
[80]. Different approaches could be used to move Sitransporters from higher accumulator plants to plants lacking Si-transporters, thus providing protection against diseases.

In Arabidopsis, it has recently been demonstrated that Si may protect plants from diseases through the SAindependent pathway. As a result, it was suggested that further work needs to be done on the SA-independent plant protection mechanisms, so that hybrid crops may be developed to cope with the changing environmental conditions [81]. Few studies have been conducted on the effect of $\mathrm{Si}$ on increased plant tolerance to insect herbivores. As a result, further research into the interactions of $\mathrm{Si}$ with the transcriptome of various varieties of plants whose $\mathrm{Si}$ uptake and accumulation ability varies (e.g. accumulators, non-accumulators) during attack by various types of insect herbivores (e.g. chewers, suckers) can provide useful insights into how $\mathrm{Si}$ alters plant gene expression in relation to insect stress.

\section{Impact of silicon on plants during favorable environmental conditions}

It was earlier thought that $\mathrm{Si}$ had little or no impact on plant metabolism under controlled conditions [82]. In contrast, at present the effects of silicon on alleviation of biotic stresses are now well understood. Silicon has a profound effect on more basic metabolic processes [21, 22]. Recently, pot-based studies on the effect of Si on Saccharum spp. hybrid growth and its protection against an insect herbivore, showed substantial enhancement in plant growth and productivity [45]. Chain et al. [76] observed that the application of silicon to control plants of Triticum aestivum changed the regulation of 47 genes, while Brunings et al. [83] demonstrated that application of silicon to normal rice plants, changed the regulation of 221 genes, 28 of which were linked with defence and stress, and the rest were linked with primary metabolic

Table 2 The role of defense-related enzymes regulated by silicon in biotic stress

\begin{tabular}{|c|c|c|c|}
\hline Stress/disease & Plant & Antioxidants & Source \\
\hline Anthracnose & Bean (Phaseolus vulgaris) & SOD, APX and GR & [141] \\
\hline Powdery mildew, crown and root rot & Cucumber (Cucumis sativus) & POD, PPOs, CHT and POD & {$[37,50]$} \\
\hline Powdery mildew and pink rot & Melon (Cucumis melo) & POD, CHT, SOD, and $\beta-1,3$-glucanase & {$[149,152]$} \\
\hline Leaf spot & Pea (Pisum sativum) & CHT and $\beta$-1,3-glucanase & {$[155]$} \\
\hline Blast, brown spot, sheath blight & Rice (Oryza sativa) & $\begin{array}{l}\text { Glucanase, POD, PPOs, phenylalanine ammonia-lyase, SOD, CAT, } \\
\text { APX, GR, lipoxygenase, Phenylalanine ammonia-lyases, CHT } \\
\text { and } \beta-1,3 \text { glucanase }\end{array}$ & $\begin{array}{l}{[51,67,116,} \\
120,163 \\
164]\end{array}$ \\
\hline Target spot & Soybean (Glycine max) & $\begin{array}{l}\text { CHT, } \beta-1-3-\text { glucanases, phenylalanine ammonia-lyases, POD and } \\
\text { PPOs }\end{array}$ & {$[165]$} \\
\hline Blast & Wheat (Triticum spp.) & $\mathrm{CHT}$ and $\mathrm{POD}$ & {$[162]$} \\
\hline Bacterial wilt and blight & Tomato (Solanum lycopersicum) & CAT, APX, SOD, GR POD and phenylalanine ammonia lyase & {$[72,166]$} \\
\hline
\end{tabular}


Table 3 The role of genes upon the application of Si subjected to biotic stress/disease

\begin{tabular}{|c|c|c|c|c|c|}
\hline Stress/disease & Plant & Functional annotation & Biological process & $\begin{array}{l}\text { Function } \\
\text { of Genes }\end{array}$ & Source \\
\hline \multirow[t]{3}{*}{ Rice blast } & Rice (Oryza sativa) & $\begin{array}{l}\text { ß-1,3-Glucanase precursor, transport of heavy metal/ } \\
\text { detoxification protein domain-containing protein, } \\
\text { pathogenic related transcriptional factor and ERF } \\
\text { domain containing protein, precursor of peroxidase, } \\
\text { resistance protein of bacterial blight and precursor of } \\
\text { peroxidase }\end{array}$ & Defense & $\uparrow$ & [83] \\
\hline & & $\begin{array}{l}\text { Stem rust tolerance protein of barley, family protein of } \\
\text { disease resistance, HSP-20 domain containing protein, } \\
\text { peroxidase, terpene synthase like protein and patho- } \\
\text { genesis related protein type-l }\end{array}$ & & $\downarrow$ & \\
\hline & & $\begin{array}{l}\text { WRKY domain containing protein of DNA binding, } \\
\text { transcriptional protein of trans-acting and R2R3 Myb } \\
\text { protein (type-P) }\end{array}$ & Regulatory & $\downarrow$ & \\
\hline Bacterial wilt & Tomatao (Solanum lycopersicum) & $\begin{array}{l}\text { Stress responsive factor, pathogenesis related protein-1, } \\
\beta \text {-glucanase, chitinase class II, peroxidase, phenyla- } \\
\text { lanine ammonia lyase, Arabinogalactan protein and } \\
\text { polygalacturonase inhibitor protein }\end{array}$ & Defense & $\uparrow$ & [98] \\
\hline \multirow[t]{3}{*}{ Rice blast } & Rice (Oryza sativa) & $\begin{array}{l}\text { Phosphoenolpyruvate carboxylase kinase, RNA-directed } \\
\text { DNA polymerase (RT) domain containing protein, } \\
\text { high pl a-glucosidase, oxalate oxidase like protein and } \\
\text { P-type ATPase }\end{array}$ & Housekeeping & $\uparrow$ & [83] \\
\hline & & $\begin{array}{l}\text { Family protein of putative cyclase, protein of transferase } \\
\text { family, Dicyp-2 cyclophilin, DNA-directed RNA poly- } \\
\text { merase-2 and tyrosine decarboxylase I }\end{array}$ & & $\downarrow$ & \\
\hline & & Cytochrome P450 monooxygenase & Photosynthetic & $\downarrow$ & \\
\hline Bacterial wilt & Tomatao (Solanum lycopersicum) & $\begin{array}{l}\text { Group of WRKY transcription factor-II, jasmonate and } \\
\text { ethylene responsive factor-III and ferredoxin-I }\end{array}$ & Regulatory & $\uparrow$ & [98] \\
\hline
\end{tabular}

Arrow indicates increase and decrease activities

mechanisms or whose functions were unknown. Van Bockhaven et al. [59] reported that $\mathrm{Si}$ changed the expression of genes involved in cell wall biosynthesis and glycolysis, as well as those of nitrogen and amino acid metabolism, and also affected the metabolism of defence hormones, namely ETH, JA and SA in rice plants.

Detmann et al. [84] showed the beneficial effects of silicon in rice plants. They concluded that the element enhanced photosynthetic capacity and, as a result, altered metabolism by stimulating amino acid remobilization, based on photosynthesis responses and transcriptomic and metabolomic profiling in paddy. According to Fleck et al. [85], Si significantly changed the root anatomy of normal grown crop plants, as well as the regulation of 265 genes, including a 25 -fold increase of a particular protein-encoding gene that can play a key role in the perception of an unknown Si signal. Furthermore, Si has been shown to delay leaf senescence in both Si-accumulating and non-accumulating plant cultivars by activating the cytokinin pathway [86].

\section{Silicon mediated defense-related enzymes}

Stress-related enzymes are strongly associated with disease tolerance, and Si has been observed to stimulate the activity of enzymes subjected to biotic stress [28, 72]. Many studies have assessed the impact of Si in disease tolerance by activating the activities of defencerelated enzymes namely, chitinase $(\mathrm{CHT})$, peroxidases (PODs), polyphenol oxidases (PPOs), $\beta$-1,3-glucanase, phenylalanine ammonia-lyase (PAL), superoxide dismutase (SOD), ascorbate peroxidase (APX), glutathione reductase (GR), catalase (CAT), lipoxygenase and glucanase $[28,72,87]$ (Table 2). Application of Si could enhance the activity of POD and CHT, which play a significant role in biotic stress. POD is involved in cell-wall reinforcement, in the final stages of lignin biosynthesis, and in the cross-linking of cell wall proteins [88]. Defence-related enzymatic responses induced by $\mathrm{Si}$ can be associated with expression of genes related to enzyme synthesis [49]. The upregulated activities of antioxidative enzymes were monitored in cucumber, turfgrass and pea plants which were infected with powdery mildew, sheath blight and rust diseases, respectively [89-93]. Previous findings indicated that Si enhances SOD, CAT, APX, GR and POD content thereby, protecting the antioxidative metabolic processes [72, 94-96]. 


\section{Silicon modulated expression of genes}

Housekeeping genes are essential for the proper functioning of cells and are expressed constitutively in all cells, regardless of the patho-physiological responses of these genes. Despite the fact that the expression of housekeeping genes is stable, some studies have found that they lose their stability when they are subjected to stress [22, 28, 83, 97]. According to Brunings et al. [83], Si application decreased the expression of essential housekeeping genes in rice under control conditions, but increased the expression of housekeeping genes to preserve cellular functions throughout pathogen infection. Siliconmediated up-regulation of housekeeping genes such as actin (ACT), alpha-tubulin (TUB), and phosphoglycerate kinase (PGK) in Ralstonia solanacearum-infected in tomatoes [98]. According to Jarosch et al. [99], the actin cytoskeleton provided the basal resistance during infection in $R$. solanacearum. As a result, the host resistance was induced by the Si-dependent upregulation of actin in tomato (Solanum lycopersicum) plants [98]. Due to lack of a high-density $\mathrm{Si}$ transporter, tomato is classified as a low-level Si accumulator (about $0.2 \%$ dry weight) [100]. Furthermore, the application of $\mathrm{Si}$ in low-accumulating plants, i.e. Solanum lycopersicum [101], Capsicum annuum [102], and Rosa spp. [103] has resulted in overcoming stress resistance. Despite the fact that housekeeping genes have a constant expression level, variation in expression levels in response to Si treatment and pathogen infection can trigger the host plant's basal defence mechanism to protect it from the pathogen (Table 3).

Silicon is associated with the metabolic mechanisms of plant-pathogen interactions, triggering host plant defence genes via a sequence of physiological and biochemical reactions and signal transductions, as well as inducing disease resistance in plants [24, 58]. Silicon could play a role in the primary response, modulating the behavior of post-elicitation intracellular signaling pathways that control the expression of defence genes involved in cell wall structural modifications, hypersensitivity responses, synthesis of hormones, antimicrobial compound synthesis, and in formation of PR proteins [24]. To demonstrate the mechanism of protection of $\mathrm{Si}$ in various pathological systems, transcriptomic and proteomic experiments have been carried out $[2,21-23,28$, $98,104]$.

The expression of genes encoding a novel proline-rich protein (PRP1) was increased under the induction of system acquired resistance in Cucumis sativus mediated by $\mathrm{Si}$, which led to cell-wall reinforcement at the site of penetration of fungi into epidermal cells [105]. The expressions of CHI-II, GLU, PGIP, and POD, which are due to virulence factors released by the pathogen to inhibit host resistance and promote host invasion, were reduced by treatment with Si during pathogen interactions in tomato plants ( $R$. solanacearum) [98]. Twenty six proteins were significantly altered by $\mathrm{Si}$ treatment in tomato plants, implying that $\mathrm{Si}$-mediated disease resistance is linked to protein changes [106]. For example, Arabidopsis infected with the fungus, Erysiphe cichoracearum showed changes in the expression of about 4000 genes. The number and/ or expression level of defence related genes enhanced in $\mathrm{Si}$ treated plants [75]. The expression of around 900 genes reacting to pathogen infection were modified in wheat plant leaves infected with Blumeria graminis f. sp. tritici, while the pathogen modified a few genes in silicon treated plants, implying that $\mathrm{Si}$ almost removed the stress due to pathogen invasion [76]. Brunings et al. [83] inoculated in the rice transcriptome, Magnaporthe ory$z a e$, and riceblast fungus. Treatment of the plant with silicon appears to eradicate the effect of pathogen invasion on the transcriptome of host plants, rather than inducing resistance through transcriptional reprogramming of defence-related genes.

\section{Silicon as a sustainable alternative}

Silicon has been shown to enhance crop resistance to a variety of biotic stresses and can be seen as an alternative to adaptive strategies $[3,10,21,22,32]$. Due to the special physical and chemical properties of Si have useful application in various sectors, including promising applications in the agri-sectors, they can easily enter into plant cells and affect the plant development by affecting their metabolism through diverse interactions, thereby triggering the potential to combat stress conditions. Thus, Si has the potential to be used as a fertilizer alone for specific crops and can be used to deliver herbicides and fertilizers in plants. The application of $\mathrm{Si}$ in agriculture may also lead to worldwide food security and safety by helping in the development of advanced varieties of crops with maximum yield. Silicon can provide green and eco-environment friendly alternatives to different synthetic fertilizers without environmental pollution. Simultaneously, the well-known positive impact on crop productivity and quality has a tremendous potential to enhance farmers' profit margin through the utilization of the alternative approach.

\section{Conclusion and future prospects}

Nowadays, there has been a lot of research which focuses on the role of $\mathrm{Si}$ in ameliorating plant tolerance to biotic stress, as well as in the regulation of signaling transduction pathways, and also in activating transcription factors in response to stress. Based on the present review, we concluded that $\mathrm{Si}$ increases plant resistance capacity to biotic stress, through a complex pathway associated with the plant defence system by activating 
transcription factors. In this review, we have discussed various aspects of $\mathrm{Si}$ and its regulatory functions during unfavorable conditions, and used key points from various relevant studies to explain how $\mathrm{Si}$ enhances stress resistance. While $\mathrm{Si}$ is associated with thousands of plant genes, it is not clear which other transcription factors and signaling proteins interact with $\mathrm{Si}$ to increase stress resistance. It will be very interesting to explore the role of Si signaling pathway, interactions with phytohormones, and crosstalk at the level of plant tissues, and at the cellular level to better understand how plants respond to environmental stresses, especially biotic stress. Overall, future research should concentrate on collecting more evidence to unravel the molecular mechanisms and the role of Si in plant tolerance to biotic stress, as well as the regulation of signal transduction pathways, and gene expressions associated in the biosynthesis of key compounds relevant to plant development.

\begin{abstract}
Abbreviations
ABA:: Abscisic acid; ACT: Actin; APX: Ascorbate peroxidase; CAT: Catalase; CHT: Chitinase; DAMPs: Damage-associated molecular patterns; ETH: Ethylene; ETI: Effector-triggered immunity; GR: Glutathione reducase; HAMPs: Herbivore-associated molecular patterns; HIPVs: Herbivore-induced plant volatiles; JA: Jasmonic acid; PAL: Phenylalanine ammonia-lyase; PAMP-PTI:: PAMP-triggered immunity; PAMPs: Pathogen-associated molecular patterns; PGK: Phosphoglycerate kinase; POD: Peroxidases; PPOs: Polyphenol oxidases; PRP1: Proline rich protein; PRRs: Pattern recognition receptors; ROS: Reactive oxygen species; SA: Salicylic acid; Si: Silicon; SOD: Superoxide dismutase; TUB: Alpha-tubulin.
\end{abstract}

\section{Acknowledgements}

We are very grateful to the Guangxi Academy of Agricultural Sciences, Nanning, Guangxi, China for providing the necessary facilities.

\section{Authors' contributions}

XPS, KK and YRL design the article. XPS, KKV, DT, XQZ, YJL, XH and CNL performed the literature search and data analysis. The original draft wrote by XPS and KKV. YRL critically revised the manuscript. All authors read and approved the final manuscript.

\section{Funding}

This study was financially supported by the Youth Program of National Natural Science Foundation of China (31901594), Fund of Guangxi Academy of Agricultural Sciences (2021YT011) and Guangxi R and D Program Fund (GK17195100)

\section{Availability of data and materials}

All the supporting data/findings are included in this article.

\section{Declarations}

Ethics approval and consent to participate

Not applicable.

\section{Consent for publication}

Not applicable.

\section{Competing interests}

None of the authors has any financial or other relationships that could lead to a conflict of interest.

\section{Author details}

${ }^{1}$ Sugarcane Research Institute, Guangxi Academy of Agricultural Sciences/Key Laboratory of Sugarcane Biotechnology and Genetic Improvement (Guangxi), Ministry of Agriculture and Rural Affairs/Guangxi Key Laboratory of Sugarcane Genetic Improvement, Nanning 530007, Guangxi, China. ${ }^{2}$ Institute of Biotechnology, Guangxi Academy of Agricultural Sciences, Nanning 530007, Guangxi, China. ${ }^{3}$ Guangxi South Subtropical Agricultural Science Research Institute, Chongzuo 532200, Guangxi, China.

Received: 1 May 2021 Accepted: 29 June 2021

Published online: 08 July 2021

\section{References}

1. Epstein E. Silicon. Annual Rev Plant Biol. 1999;50:641-64.

2. Farooq MA, Dietz K-J. Silicon as versatile player in plant and human biology: overlooked and poorly understood. Front Plant Sci. 2015;6:994. https://doi.org/10.3389/fpls.2015.00994.

3. Verma KK, Singh P, Song XP, Malviya MK, Singh RK, Chen GL, Solomon S, Li YR. Mitigating climate change for sugarcane improvement: role of silicon in alleviating abiotic stresses. Sugar Tech. 2020;22:741-9.

4. Rezanka T, Sigler K. Biologically active compounds of semi metals. Stud Nat Prod Chem. 2008:35:835-921.

5. Redei GP. "Silicon (Si)," in Encyclopedia of Genetics, Genomics, Proteomics, and Informatics (Springer), 2008; pp. 1817.

6. Das S, Chattopadhyay UK. Role of silicon in modulating the internal morphology and growth of Mycobacterium tuberculosis. Ind J Tub. 2000;47:87-91.

7. Cornelis JT, Delvaux B, Georg RB, Lucas Y, Ranger J, Opfergelt S. Tracing the origin of dissolved silicon transferred from various soilplant systems towards rivers: a review. Biogeoscience. 2011;8:89-112.

8. Desplanques V, Cary L, Mouret JC, Trolard F, Bourrie G, Grauby O, Meunier JD. Silicon transfers in a rice field in Camargue (France). J Geochem Explor. 2006:88:190-3.

9. Epstein E. Silicon: its manifold roles in plants. Ann Appl Biol. 2009;155:155-60.

10. Debona D, Rodrigues FA, Datnoff LE. Silicon's role in abiotic and biotic plant stresses. Annu Rev Phytopathol. 2017;55:85-107.

11. Verma KK, Song XP, Verma CL, Malviya MK, Guo DJ, Rajput VD, Sharma A, Wei KJ, Chen GL, Solomon S, Li YR. Predication of photosynthetic leaf gas exchange of sugarcane (Saccharum spp.) leaves in response to leaf positions to foliar spray of potassium salt of active phosphorus under limited water irrigation. ACS Omega. 2021;6:2396-409.

12. Verma KK, Song $X P$, Lin $B$, Guo DJ, Singh M, Rajput VD, Singh RK, Singh P, Sharma A, Malviya MK, Chen GL, Li YR. Silicon induced drought tolerance in crop plants: physiological adaptation strategies. SILICON. 2021. https://doi.org/10.1007/s12633-021-01071-x.

13. Savant NK, Synder GH, Datnoff LE. Silicon management and sustainable rice production. Adv Agron. 1997;58:151-91.

14. de Saussure NT. Recherches chimiques sur la vegetation (Chemical Research on Vegetation). Paris: Nyon. 1804.

15. Hall AD, Morison CGT. On the function of silica in the nutrition of cereals. Part I. Proc Royal Soc London B. 1906;77:455-77.

16. Guntzer F, Keller C, Meunier J-D. Benefits of plant silicon for crops: a review. Agron Sust Develop. 2012;2012(32):201-13.

17. IPNI. Silicon. Nutri-facts, 2015; No. 14. http://www.ipni.net/publication/ nutrifacts-na.nsf/0/A7B4AB4D35C153BF85257ECE006E0E34/\$FILE/Nutri Facts-NA-14.pdf. Accessed 05 Mar 2021.

18. Richmond KE, Sussman M. Got silicon? The non-essential beneficial plant nutrient. Curr Opinion Plant Biol. 2003;6:268-72.

19. Lewin J, Reimann BEF. Silicon and plant growth. Annu Rev Plant Physiol. 1969;20:289-304.

20. Epstein E. The anomaly of silicon in plant biology. Proc Natl Acad Sci USA. 1994;91:11-7.

21. Frew A, Weston LA, Reynolds OL, Gurr GM. The role of silicon in plant biology: a paradigm shift in research approach. Ann Bot. 2018;121:1265-73.

22. Coskun D, Deshmukh R, Sonah H, Menzies JG, Reynolds O, Ma JF, Kronzucker HJ, Belanger RR. The controversies of silicon's role in plant Biology. New Phytol. 2019;221:67-85. 
23. Chen D, Wang S, Yin L, Deng X. How does silicon mediate plant water uptake and loss under water deficiency? Front Plant Sci. 2018;9:281. https://doi.org/10.3389/fpls.2018.00281.

24. Fauteux F, Remus-Borel W, Menzies JG, Belanger RR. Silicon and plant disease resistance against pathogenic fungi. FEMS Microbiol Lett. 2005;249:1-6

25. Reynolds OL, Keeping MG, Meyer JH. Silicon-augmented resistance of plants to herbivorous insects: a review. Ann Appl Biol. 2009;155:171-86.

26. Reynolds OL, Padula MP, Zeng R, Gurr GM. Silicon: potential to promote direct and indirect effects on plant defense against arthropod pests in agriculture. Front Plant Sci. 2016;7:744. https://doi.org/10.3389/fpls. 2016.00744.

27. Cooke J, Leishman MR. Consistent alleviation of abiotic stress with silicon addition: a meta-analysis. Funct Ecol. 2016;30:1340-57.

28. Manivannan A, Ahn Y-K. Silicon regulates potential genes involved in major physiological processes in plants to combat stress. Front Plant Sci. 2017;8:1346. https://doi.org/10.3389/fpls.2017.01346.

29. Ma JF, Yamaji N. A cooperative system of silicon transport in plants. Trends Plant Sci. 2015;20:435-42.

30. Cooke J, DeGabriel JL, Hartley SE. The functional ecology of plant silicon: geoscience to genes. Funct Ecol. 2016;30:1270-6.

31. Verma KK, Wu KC, Verma CL, Li DM, Malviya MK, Singh RK, Singh P, Chen GL, Song XP, Li YR. Developing mathematical model for diurnal dynamics of photosynthesis in Saccharum officinarum responsive to different irrigation and silicon application. Peer J. 2020;8: e10154. https://doi.org/ 10.7717/peerj.10154.

32. Luyckx M, Hausman J-F, Lutts S, Guerriero G. Silicon and plants: current knowledge and technological perspectives. Front Plant Sci. 2017;8:411. https://doi.org/10.3389/fpls.2017.00411.

33. Sakr $\mathrm{N}$. The role of silicon (Si) in increasing plant resistance against insect pests review article. Acta Phytopathol Entomolog Hungarica. 2017; $52: 1-19$

34. Hu S, Wang C, Sanchez DL, Lipka AE, Liu P, Yin Y, Blanco M, Lübberstedt T. Gibberellins promote Brassinosteroids action and both increase heterosis for plant height in maize (Zea mays L.). Front Plant Sci. 2017;8:1039. https://doi.org/10.3389/fpls.2017.01039.

35. Wu W, Zhang Q, Ervin EH, Yang Z, Zhang X. Physiological mechanism of enhancing salt stress tolerance of perennial ryegrass by 24-epibrassinolide. Front Plant Sci. 2017;8:1017.

36. Anwar A, Liu Y, Dong R, Bai L, Yu X, Li Y. The physiological and molecular mechanism of brassinosteroid in response to stress: a review. Biol Res. 2018;51:46. https://doi.org/10.1186/s40659-018-0195-2

37. Chérif M, Asselin A, Bélanger RR. Defense responses induced by soluble silicon in cucumber roots infected by Pythium spp. Phytopathology. 1994;84:236-42

38. Rodrigues FA, Dallagnol LJ, Duarte HSS, Datnoff LE. Silicon control of foliar diseases in monocots and dicots. In: Rodrigues FA, Datnoff LE, editors. Silicon and plant diseases. Cham: Springer; 2015. p. 67-108.

39. McNaughton SJ, Tarrants JL. Grass leaf silicification: natural selection for an inducible defense against herbivores. Proc Nat Acad Sci USA. 1983:80:790-1.

40. Katz O. Silica phytoliths in angiosperms: phylogeny and early evolutionary history. New Phytol. 2015;208:642-6.

41. Kim SG, Kim KW, Park EW, Choi D. Silicon-induced cell wall fortification of rice leaves: a possible cellular mechanism of enhanced host resistance to blast. Phytopathology. 2002;92:1095-103.

42. Massey FP, Ennos AR, Hartley SE. Grasses and the resource availability hypothesis: the importance of silica-based defences. J Ecol. 2007;95:414-24

43. Jeer M, Telugu UM, Voleti SR, Padmakumari AP. Soil application of silicon reduces yellow stem borer, Scirpophaga incertulas (Walker) damage in rice. J Appl Entomol. 2017;141:189-201.

44. Massey FP, Hartley SE. Experimental demonstration of the antiherbivore effects of silica in grasses: impacts on foliage digestibility and vole growth rates. Proc Royal Soc London B: Biol Sci. 2006;273:2299-304.

45. Frew A, Powell JR, Sallam N, Allsopp PG, Johnson SN. Trade-offs between silicon and phenolic defenses may explain enhanced performance of root herbivores on phenolic-rich plants. J Chem Ecol. 2016;42:768-71.
46. Ryalls JMW, Hartley SE, Johnson SN. Impacts of silicon-based grass defences across trophic levels under both current and future atmospheric $\mathrm{CO}_{2}$ scenarios. Biol Let. 2017;13:20160912.

47. Hartley SE, DeGabriel JL. The ecology of herbivore-induced silicon defences in grasses. Funct Ecol. 2016;30:1311-22.

48. Chérif M, Benhamou N, Menzies JG, Bélanger RR. Silicon induced resistance in cucumber plants against Pythium ultimum. Physiol Mol Plant Path. 1992;41:411-25.

49. Rahman A, Wallis CM, Uddin W. Silicon-induced systemic defense responses in perennial ryegrass against infection by Magnaporthe oryzae. Phytopathology. 2015;105:748-57.

50. Liang $X$, Wang H, Hu Y, Mao L, Sun L, Dong T, Nan W, Bi Y. Silicon does not mitigate cell death in cultured tobacco BY-2 cells subjected to salinity without ethylene emission. Plant Cell Rep. 2015:34:331-43.

51. Cai K, Gao D, Luo S, Zeng R, Yang J, Zhu X. Physiological and cytological mechanisms of silicon-induced resistance in rice against blast disease. Physiol Plant. 2008;134:324-33.

52. Fortunato $A A$, da Silva $W L$, Rodrigues FÁ. Phenylpropanoid pathway is potentiated by silicon in the roots of banana plants during the infection process of Fusarium oxysporum f. sp. cubense. Phytopathology. 2013;104:597-603.

53. Glazebrook J. Contrasting mechanisms of defense against biotrophic and necrotrophic pathogens. Annual Rev Phytopathol. 2005:2005(43):205-27.

54. Wu J, Baldwin IT. New insights into plant responses to the attack from insect herbivores. Annual Rev Genetics. 2010;44:1-24.

55. Ye M, Song $Y$, Long J, Wang R, Baerson SR, Pan Z, Zhu-Salzman K Xie J, Cai K, Luo S, Zeng R. Priming of jasmonate-mediated antiherbivore defense responses in rice by silicon. Proc Nat Acad Sci USA. 2013;110:E3631-9.

56. Kvedaras OL, An M, Choi YS, Gurr GM. Silicon enhances natural enemy attraction and biological control through induced plant defences. Bull Entomol Res. 2010;2010(100):367-71.

57. Liu J, Zhu J, Zhang P, Han L, Reynolds OL, Zeng R, Wu J, Shao Y, You M, Gurr GM. Silicon supplementation alters the composition of herbivore induced plant volatiles and enhances attraction of parasitoids to infested rice plants. Front Plant Sci. 2017;8:1265. https://doi.org/10. 3389/fpls.2017.01265.

58. Vivancos J, Labbe C, Menzies JG, Bélanger RR. Silicon-mediated resistance of Arabidopsis against powdery mildew involves mechanisms other than the salicylic acid (SA)-dependent defence pathway. Mol Plant Pathol. 2015;16:572-82.

59. Van Bockhaven J, Spíchal L, Novák O, Strnad M, Asano T, Kikuchi S, Hofte $\mathrm{M}$, Vleesschauwer DD. Silicon induces resistance to the brown spot fungus Cochliobolus miyabeanus by preventing the pathogen from hijacking the rice ethylene pathway. New Phytol. 2015;206:761-73.

60. Coskun D, Britto DT, Huynh WQ, Kronzucker HJ. The role of silicon in higher plants under salinity and drought stress. Front Plant Sci. 2016;7:1072. https://doi.org/10.3389/fpls.2016.01072.

61. Dodds PN, Rathjen JP. Plant immunity: towards an integrated view of plant-pathogen interactions. Nat Rev Genet. 2010;11:539-48.

62. Erb M, Meldau S, Howe GA. Role of phytohormones in insect-specific plant reactions. Trends in Plant Sci. 2012;17:250-9.

63. Boller T, Felix G. A renaissance of elicitors: perception of microbeassociated molecular patterns and danger signals by pattern-recognition receptors. Annu Rev Plant Biol. 2009;60:379-406.

64. Musser RO, Hum-Musser SM, Eichenseer H, Peiffer M, Ervin G, Murphy JB, Felton GW. Herbivory: caterpillar saliva beats plant defences. Nature. 2002;2002(416):599-600.

65. Giraldo MC, Valent B. Filamentous plant pathogen effectors in action. Nat Rev Microbiol. 2013;11:800-14.

66. Van Bockhaven J, De Vleesschauwer D, Hofte M. Towards establishing broad-spectrum disease resistance in plants: silicon leads the way. J Exp Bot. 2013;64:1281-93

67. Domiciano GP, Cacique IS, Chagas Freitas C, de Filippi MCC, DaMatta FM, do Vale FXR, Rodrigues FA. Alterations in gas exchange and oxidative metabolism in rice leaves infected by Pyricularia oryzae are attenuated by silicon. Phytopathology. 2015;105:738-47.

68. Yang L, Han Y, Li P, Li F, Ali S, Hou M. Silicon amendment is involved in the induction of plant defense responses to a phloem feeder. Scientific Reports. 2017;7:4232. https://doi.org/10.1038/s41598-017-04571-2. 
69. Debona D, Rodrigues FA, Rios JA, Nascimento KJT, Silva LC. The effect of silicon on antioxidant metabolism of wheat leaves infected by Pyricularia oryzae. Plant Pathol. 2014;63:581-9.

70. Ramputh Al, Arnason JT, Cass L, Simmonds JA. Reduced herbivory of the European corn borer (Ostrinia nubilalis) on corn transformed with germin, a wheat oxalate oxidase gene. Plant Sci. 2002;162:431-40.

71. Torres MA. ROS in biotic interactions. Physiol Plant. 2010;138:414-29.

72. Gulzar N, Ali S, Shah MA, Kamili AN. Silicon supplementation improves early blight resistance in Lycopersicon esculentum Mill. by modulating the expression of defense-related genes and antioxidant enzymes. 3Biotech. 2021;11:232. https://doi.org/10.1007/s13205-021-02789-6.

73. Thoma I, Loeffler C, Sinha AK, Gupta M, Krischke M, Steffan B, Roitsch T, Mueller MJ. Cyclopentenone isoprostanes induced by reactive oxygen species trigger defense gene activation and phytoalexin accumulation in plants. Plant J. 2003;34:363-75.

74. Martin-Jézéquel V, Hildebrand M, Brzezinski MA. Silicon metabolism in diatoms: implications for growth. J Phycol. 2000;36:821-40.

75. Fauteux F, Chain F, Belzile F, Menzies JG, Bélanger RR. The protective role of silicon in the Arabidopsis-powdery mildew pathosystem. Proc Nat Acad Sci USA. 2006:103:17554-9.

76. Chain F, Côté-Beaulieu C, Belzile F, Menzies JG, Bélanger RR. A comprehensive transcriptomic analysis of the effect of silicon on wheat plants under control and pathogen stress conditions. Mol Plant-Microbe Interactions. 2009;22:1323-30.

77. Salim M, Saxena RC. Iron, silica, and aluminum stresses and varietal resistance in rice: effects on white backed plant hopper. Crop Sci. 1992;32:212-9.

78. Correa RS, Moraes JC, Auad AM, Carvalho GA. Silicon and acibenzolarS-methyl as resistance inducers in cucumber, against the whitefly Bemisia tabaci (Gennadius) (Hemiptera: Aleyrodidae) biotype B. Neotrop Entomol. 2005:34:429-33.

79. Swain BN, Prasad JS. Influence of silica content in the roots of rice varieties on the resistance to root-knot nematodes. Ind J Nematol. 1988;18:360-1.

80. Malhotra CH, Kapoor R, Ganjewala D. Alleviation of abiotic and biotic stresses in plants by silicon supplementation. Scientia. 2016;13:59-73.

81. Vivancos J, Deshmukh R, Grégoire C, Rémus-Borel W, Belzile F, Bélanger RR. Identification and characterization of silicon efflux transporters in horsetail (Equisetum arvense). J Plant Physiol. 2016;200:82-9.

82. Ma JF. Role of silicon in enhancing the resistance of plants to biotic and abiotic stresses. Soil Sci Plant Nutr. 2004;50:11-8.

83. Brunings AM, Datnoff LE, Ma JF, Mitani N, Nagamura Y, Rathinasabapathi B, Kirst M. Differential gene expression of rice in response to silicon and rice blast fungus Magnaporthe oryzae. Ann Appl Biol. 2009;2009(155):161-70

84. Detmann KC, Araújo WL, Martins SCV, Sanglard LMVP, Reis JV, Detmann E, Rodrigues FA, Nunes-Nesi A, Fernie AR, DaMatta FM. Silicon nutrition increases grain yield, which, in turn, exerts a feed-forward stimulation of photosynthetic rates via enhanced mesophyll conductance and alters primary metabolism in rice. New Phytol. 2012;196:752-62.

85. Fleck AT, Nye T, Repenning C, Stahl F, Zahn M, Schenk MK. Silicon enhances suberization and lignification in roots of rice (Oryza sativa). J Exp Bot. 2011:62:2001-11.

86. Markovich O, Steiner E, Kouril S, Tarkowski P, Aharoni A, Elbaum R. Silicon promotes cytokinin biosynthesis and delays senescence in Arabidopsis and Sorghum. Plant Cell Environ. 2017;40:1189-96.

87. Waewthongrak W, Pisuchpen S, Leelasuphakul W. Effect of Bacillus subtilis and chitosan applications on green mold (Penicillium digitatum Sacc.) decay in citrus fruit. Postharvest Biol Technol. 2015;99:44-9.

88. Brisson LF, Tenhaken R, Lamb C. Function of oxidative crosslinking of cell wall structural proteins in plant disease resistance. Plant Cell. 1994:6:1703-12.

89. Guoqiang W. Effects of silicon supply and Sphaerotheca fuliginea inoculation on resistance of cucumber seedlings against powdery mildew. J Appl Ecol. 2004;15:2147-51.

90. Zhang GL, Dai QG, Zhang HC. Silicon application enhances resistance to sheath blight (Rhizoctonia solani) in rice. J Plant Physiol Mol Biol. 2006:32:600-6.

91. Zhu Z, Wei G, Li J, Qian Q, Yu J. Silicon alleviates salt stress and increases antioxidant enzymes activity in leaves of salt stressed cucumber (Cucumis sativus L.). Plant Sci. 2004;167:527-33.
92. He Y, Xiao H, Wang H, Chen Y, Yu M. Effect of silicon on chilling-induced changes of solutes, antioxidants, and membrane stability in seashore Paspalum turfgrass. Acta Physiol Plant. 2010;32:487-94.

93. Tripathi DK, Singh VP, Prasad SM, Chauhan DK, Dubey NK. Silicon nanoparticles (SiNp) alleviate chromium (VI) phytotoxicity in Pisum sativum (L.) seedlings. Plant Physiol Biochem. 2015;96:189-98.

94. Shi Y, Zhang Y, Yao H, Wu J, Sun H, Gong H. Silicon improves seed germination and alleviates oxidative stress of bud seedlings in tomato under water deficit stress. Plant Physiol Biochem. 2014;78:27-36.

95. Shi Y, Zhang Y, Han W, Feng R, Hu Y, Guo J, Gong H. Silicon enhances water stress tolerance by improving root hydraulic conductance in Solanum lycopersicum L. Front Plant Sci. 2016;7:196.

96. Al-Huqail AA, Alqarawi AA, Hashem A, Ahmad MJ. Silicon supplementation modulates antioxidant system and osmolyte accumulation to balance salt stress in Acacia gerrardii Benth. Saudi J Biol Sci. 2019:26:1856-64.

97. Jain M, Nijhawan A, Tyagi AK, Khurana JP. Validation of housekeeping genes as internal control for studying gene expression in rice by quantitative real-time PCR. Biochem Biophys Res Commun. 2006;345:646-51.

98. Ghareeb H, Bozsó Z, Ott PG, Repenning C, Stahl F, Wydra K. Transcriptome of silicon-induced resistance against Ralstonia solanacearum in the silicon non-accumulator tomato implicates priming effect. Physiol Mol Plant Pathol. 2011;75:83-9.

99. Jarosch B, Collins NC, Zellerhoff N, Schaffrath U. RAR1, ROR1, and the actin cytoskeleton contribute to basal resistance to Magnaporthe grisea in barley. Mol Plant-Microbe Interact. 2005;18:397-404.

100. Ma JF, Yamaji N. Silicon uptake and accumulation in higher plants. Trends Plant Sci. 2006;11:392-7.

101. Romero-Aranda MR, Jurado O, Cuartero J. Silicon alleviates the deleterious salt effect on tomato plant growth by improving plant water status. J Plant Physiol. 2006;163:847-55.

102. Jayawardana HARK, Weeahewa HLD, Saparamadu MDJS. Enhanced resistance to anthracnose disease in chili pepper (Capsicum annuum L.) by amendment of the nutrient solution with silicon. J Horticult Sci Biotechnol. 2015;90:557-62.

103. Soundararajan P, Manivannan A, Ko CH, Jeong BR. Silicon enhanced redox homeostasis and protein expression to mitigate the salinity stress in rosa hybrida 'Rock Fire.' J Plant Growth Regul. 2017:37:1-19.

104. Nwugo CC, Huerta AJ. The effect of silicon on the leaf proteome of rice (Oryza sativa L.) plants under cadmium-stress. J Proteome Res. 2011;10:518-28.

105. Kauss H, Kai S, Franke R, Gilbert S, Dietrich RA, Kröger N. Silica deposition by a strongly cationic proline-rich protein from systemically resistant cucumber plants. Plant J. 2003;33:87-95.

106. Chen Y, Liu M, Wang L, Lin W, Fan X, Cai K. Proteomic characterization of silicon-mediated resistance against Ralstonia solanacearum in tomato. Plant Soil. 2014;387:425-40

107. Somapala K, Weerahewa D, Thrikawala S. Silicon rich rice hull amended soil enhances anthracnose resistance in tomato. Proc Food Sci. 2016;6:190-3

108. Huang C-H, Roberts PD, Datnoff LE. Silicon suppresses Fusarium crown and root rot of tomato. J Phytopathol. 2011;159:546-54.

109. Andrade CCL, Resende RS, Rodrigues F, Ferraz HGM, Moreira WR, Oliveira JR, Mariano RLR. Silicon reduces bacterial speck development on tomato leaves. Trop Plant Pathol. 2013:38:436-42.

110. Han Y, Li P, Gong S, Yang L, Wen L, Hou M. Defense responses in rice induced by silicon amendment against infestation by the leaf folder Cnaphalocrocis medinalis. PLoS ONE. 2015;11:e0153918.

111. He W, Yang M, Li Z, Qiu J, Liu F, Qu X, Qiu Y, Li R. High levels of silicon provided as a nutrient in hydroponic culture enhances rice plant resistance to brown plant hopper. Crop Prot. 2015;67:20-5.

112. Nascimento AM, Assis FA, Moraes JC, Sakomura R. Naopreferencia a Spodopterafrugiperda (Lepidoptera: Noctuidae) induzi daemarrozpelaaplicaçao de silício. Braz J Agric Sci Rev Brasil Ciencias Agrarias. 2014;9:215-8.

113. Sidhu JK, Stout MJ, Blouin DC, Datnoff LE. Effect of silicon soil amendment on performance of sugarcane borer, Diatraea saccharalis (Lepidoptera: Crambidae) on rice. Bull Entomol Res. 2013;103:656-64.

114. Rodrigues F, Benhamou N, Datnoff LE, Jones JB, Bélanger RR. Ultrastructural and cytochemical aspects of silicon-mediated rice blast resistance Phytopathology. 2003;93:535-46. 
115. Hayasaka T, Fujii H, Ishiguro K. The role of silicon in preventing appressorial penetration by the rice blast fungus. Phytopathology. 2008;98:1038-44

116. Dallagnol LJ, Rodrigues FA, Damatta FM, Mielli MV, Pereira SC. Deficiency in silicon uptake affects cytological, physiological, and biochemical events in the rice-Bipolaris oryzae interaction. Phytopathology. 2011;101:92-104.

117. Dallagnol LJ, Rodrigues FA, Mielli MV. Silicon improves the emergence and sanity of rice seedlings obtained from seeds infected with Bipolaris oryzae. Trop Plant Pathol. 2013;38:478-84.

118. Tatagiba SD, Damatta FM, Rodrigues FA. Silicon partially preserves the photosynthetic performance of rice plants infected by Monographella albescens. Ann Appl Biol. 2016;168:111-21.

119. Araujo L, Paschoalino RS, Rodrigues F. Microscopic aspects of silicon-mediated rice resistance to leaf scald. Phytopathology. 2015;106:132-41.

120. Schurt DA, Cruz MF, Nascimento KJ, Filippi MC, Rodrigues FA. Silicon potentiates the activities of defense enzymes in the leaf sheaths of rice plants infected by Rhizoctonia solani. Trop Plant Pathol. 2014;39:457-63.

121. Vilela M, Moraes JC, Alves E, Santos-Cividanes TM, Santos FA. Induced resistance to Diatraeasaccharalis (Lepidoptera: Crambidae) via silicon application in sugarcane. Rev Colomb Entomol. 2014;40:44-8.

122. Keeping MG, Meyer JH, Sewpersad C. Soil silicon amendments increase resistance of sugarcane to stalk borer Eldana saccharina Walker (Lepidoptera: Pyralidae) under field conditions. Plant Soil. 2013;363:297-318.

123. Ramouthar PV, Caldwell PM, Mcfarlane SA. Effect of silicon on the severity of brown rust of sugarcane in South Africa. Eur J Plant Pathol. 2015;145:53-60.

124. de Souza PV, Machado BR, Zanuncio JC, Araújo MS, Alves GCS, de Jesus FG. Cultivation of resistant soybean varieties and application of silicon (Si) on biology of'Euschistus heros' (Hemiptera: Pentatomidae). Aust J Crop Sci. 2016;10:1404.

125. Ghanmi D, Mcnally DJ, Benhamou N, Menzies JG, Bélanger RR. Powdery mildew of Arabidopsis thaliana: a pathosystem for exploring the role of silicon in plant-microbe interactions. Physiol Mol Plant Pathol. 2004;64:189-99.

126. Kablan L, Lagauche A, Delvaux B, Legrève A. Silicon reduces black sigatoka development in banana. Plant Dis. 2012;96:273-8.

127. Fortunato AA, Rodrigues F, Baroni JCP, Soares GCB, Rodriguez MAD, Pereira OL. Silicon suppresses Fusarium wilt development in banana plants. J Phytopathol. 2012;160:674-9.

128. Vermeire ML, Kablan L, Dorel M, Delvaux B, Risède JM, Legrève A. Protective role of silicon in the banana-Cylindrocladium spathiphylli pathosystem. Eur J Plant Pathol. 2011;131:621-30.

129. Mburu K, Oduor R, Mgutu A, Tripathi L. Silicon application enhances resistance to xanthomonas wilt disease in banana. Plant Pathol. 2015;2015(65):807-18.

130. Wiese J, Wiese H, Schwartz J, Schubert S. Osmotic stress and silicon act additively in enhancing pathogen resistance in barley against barley powdery mildew. J Plant Nutr Soil Sci. 2005;168:269-74.

131. Rodrigues F, Duarte HSS, Rezende DC, Filho JAW, Korndörfer GH, Zambolim L. Foliar spray of potassium silicate on the control of angular leaf spot on beans. J Plant Nutr. 2010;33:2082-93.

132. Parthasarathy $S$, Jaiganesh V. Plant activator and silicon nutrient mediated resistance against powdery mildew of Black gram (Vigna mungo L. Hepper). Glob J Res Anal. 2016;4:48-9.

133. Uriarte RF, Shew HD, Bowman DC. Effect of soluble silica on brown patch and dollar spot of creeping bentgrass. J Plant Nutr. 2004;27:325-39.

134. Ratnayake RMRNK, Daundasekera WAM, Ariyarathne HM, Ganehenege MY. Some biochemical defense responses enhanced by soluble silicon in bitter gourd-powdery mildew pathosystem. Australas Plant Pathol. 2016:45:425-33.

135. Jayawardana HARK, Weerahewa HLD, Saparamadu MDJS. The mechanisms underlying the Anthracnose disease reduction by rice hull as a silicon source in capsicum (Capsicum annuum L.) grown in simplified hydroponics. Proc Food Sci. 2016;6:147-50.

136. Qin GZ, Tian SP. Enhancement of biocontrol activity of Cryptococcus laurentii by silicon and the possible mechanisms involved. Phytopathology. 2005;95:69-75.
137. Liu L, Guo Y, Bi Y, Li M, Zhao J, Zhao H. Inhabited mechanisms of silicon compounds against Fusarium rot (Fusarium spp.) of postharvest Chinese cantaloupe. J Food Process Preserv. 2009;33:187-202.

138. Guo Y, Liu L, Zhao J, Bi Y. Use of silicon oxide and sodium silicate for controlling Trichothecium roseum postharvest rot in Chinese cantaloupe (Cucumis melo L.). Int J Food Sci Techol. 2007;42:1012-8.

139. Carré-Missio V, Rodrigues FA, Schurt DA, Resende RS, Souza NFA, Rezende DC, Moreira WR, Zambolim L. Effect of foliar-applied potassium silicate on coffee leaf infection by Hemileia vastatrix. Ann Appl Biol. 2014; 164:396-403.

140. Silva R, Oliveira R, Nascimento K, Rodrigues F. Biochemical responses of coffee resistance against Meloidogyne exigua mediated by silicon. Plant Pathol. 2010;59:586-93.

141. Polanco LR, Rodrigues FA, Nascimento KJ, Cruz MF, Curvelo CR, Damatta FM, Vale FX. Photosynthetic gas exchange and antioxidative system in common bean plants infected by Colletotrichum lindemuthianum and supplied with silicon. Trop Plant Pathol. 2014;39:35-42.

142. Rodrigues FA, Polanco LR, Duarte HSS, Resende RS, Do Vale FXR. Photosynthetic gas exchange in common bean submitted to foliar sprays of potassium silicate, sodium molybdate and fungicide and infected with Colletotrichum lindemuthianum. J Phytopathol. 2015;163:554-9.

143. Whan JA, Dann EK, Aitken EA. Effects of silicon treatment and inoculation with Fusarium oxysporum f. sp. vasinfectum on cellular defences in root tissues of two cotton cultivars. Ann Bot. 2016;118:219-26.

144. Miyake Y, Takahashi E. Effect of silicon on the growth of solution-cultured cucumber plant. Soil Sci Plant Nutr. 1983;29:71-83.

145. Menzies J, Ehret D, Glass A, Samuels A. The influence of silicon on cytological interactions between Sphaerotheca fuliginea and Cucumis sativus. Physiol Mol Plant Pathol. 1991;39:403-14.

146. Menzies J, Bowen P, Ehret D, Glass AD. Foliar applications of potassium silicate reduce severity of powdery mildew on cucumber, muskmelon, and zucchini squash. J Am Soc Hortic Sci. 1992;117:902-5.

147. Fawe A, Abou-Zaid M, Menzies J, Bélanger R. Silicon-mediated accumulation of flavonoid phytoalexins in cucumber. Phytopathol. 1998:88:396-401.

148. Liang YC, Sun WC, Si J, Römheld V. Effects of foliar- and root-applied silicon on the enhancement of induced resistance to powdery mildew in Cucumis sativus. Plant Pathol. 2005;54:678-85.

149. Bi Y, Tian SP, Guo YR, Ge YH, Qin GZ. Sodium silicate reduces postharvest decay on Hami melons: induced resistance and fungistatic effects. Plant Dis. 2015;90:279-83.

150. Garibaldi A, Gilardi G, Cogliati EE, Gullino ML. Silicon and increased electrical conductivity reduce downy mildew of soilless grown lettuce. Eur J Plant Pathol. 2011;132:123-32.

151. Conceicao CS, Felix KCS, Mariano RLR, Medeiros EV, Souza EB. Combined effect of yeast and silicon on the control of bacterial fruit blotch in melon. Sci Hortic. 2014;174:164-70.

152. Dallagnol L, Rodrigues F, Pascholati S, Fortunato A, Camargo L. Comparison of root and foliar applications of potassium silicate in potentiating post-infection defences of melon against powdery mildew. Plant Pathol. 2015:64:1085-93.

153. Li W, Bi Y, Ge Y, Li Y, Wang J, Wang Y. Effects of postharvest sodium silicate treatment on pink rot disease and oxidative stress-antioxidative system in muskmelon fruit. Eur Food Res Technol. 2011;234:137-45.

154. Najihah NI, Hanafi MM, Idris AS, Hakim MA. Silicon treatment in oil palms confers resistance to basal stem rot disease caused by Ganoderma boninense. Crop Prot. 2015:67:151-9.

155. Dann EK, Muir S. Peas grown in media with elevated plant-available silicon levels have higher activities of chitinase and b-1, 3-glucanase, are less susceptible to a fungal leaf spot pathogen and accumulate more foliar silicon. Australas Plant Pathol. 2002;31:9-13.

156. Deepak S, Manjunath G, Manjula S, Niranjan-Raj S, Geetha N, Shetty HS. Involvement of silicon in pearl millet resistance to downy mildew disease and its interplay with cell wall proline/hydroxyproline-rich glycoproteins. Australas Plant Pathol. 2008;37:498-504.

157. McDonagh D, Hunter A. Effect of silicon application on Lolium perenne development and Fusarium control. Acta Hortic. 2011;917:195-201. https://doi.org/10.17660/ActaHortic.2011.917.25

158. Lepolu Torlon J, Heckman J, Simon J, Wyenandt C. Silicon soil amendments for suppressing powdery mildew on pumpkin. Sustainability. 2016;8:293. https://doi.org/10.3390/su8040293. 
159. Guevel MH, Menzies JG, Bélanger RR. Effect of root and foliar applications of soluble silicon on powdery mildew control and growth of wheat plants. Eur J Plant Pathol. 2007;119:429-36.

160. Moldes CA, De Lima Filho OF, Merini LJ, Tsai SM, Camina JM. Occurrence of powdery mildew disease in wheat fertilized with increasing silicon doses: a chemometric analysis of antioxidant response. Acta Physiol Plant. 2016;38:206. https://doi.org/10.1007/s11738-016-2217-4.

161. Silva WLD, Cruz MFA, Fortunato AA, Rodrigues F. Histochemical aspects of wheat resistance to leaf blast mediated by silicon. Sci Agric 2015;72:322-7.

162. Filha MSX, Rodrigues FA, Domiciano GP, Oliveira HV, Silveira PR, Moreira WR. Wheat resistance to leaf blast mediated by silicon. Australas Plant Pathol. 2011:40:28-38

163. Rodrigues FA, Jurick WM, Datnoff LE, Jones JB, Rollins JA. Silicon influences cytological and molecular events in compatible and incompatible rice-Magnaporthe grisea interactions. Physiol Mol Plant Pathol. 2005;66:144-59.
164. Souza ACA, Sousa TP, Cortes MVB, Rodrigues F, Silva GB, Filippi MCC. Enzyme-induced defense response in the suppression of rice leaf blast (Magnaporthe oryzae) by silicon fertilization and bioagents. Int J Res Stud Biosci. 2015;3:22-32.

165. Fortunato AA, Debona D, Bernardeli AMA, Rodrigues FA. Defencerelated enzymes in soybean resistance to target spot. J Phytopathol. 2015;163:731-42.

166. Kurabachew H, Stahl F, Wydra K. Global gene expression of rhizobacteria-silicon mediated induced systemic resistance in tomato (Solanum lycopersicum) against Ralstonia solanacearum. Physiol Mol Plant Pathol. 2013;84:44-52.

\section{Publisher's Note}

Springer Nature remains neutral with regard to jurisdictional claims in published maps and institutional affiliations.
Ready to submit your research? Choose BMC and benefit from:

- fast, convenient online submission

- thorough peer review by experienced researchers in your field

- rapid publication on acceptance

- support for research data, including large and complex data types

- gold Open Access which fosters wider collaboration and increased citations

- maximum visibility for your research: over $100 \mathrm{M}$ website views per year

At BMC, research is always in progress.

Learn more biomedcentral.com/submissions 